\title{
ForTIFICAȚIA FRUMUȘICĂI: UN ŞANȚ DE APĂRARE DIN ENEOLITIC LA BODEȘTI (JUD. NEAMȚ)
}

ROXANA MUNTEANU, DANIEL GARVĂN

\section{REZUMAT:}

Cercetările arheologice efectuate în perioada 2011-2013 la Bodești au verificat și confirmat unele date cunoscute anterior cu privire la locuirea preistorică de aici. Situl s-a format în urma locuirilor cucuteniene succesive (din fazele A, A-B și B), la aspectul actual contribuind și frecventările umane din epoca bronzului (perioadele timpurie și mijlocie).

Poziția dominantă a platoului, înconjurat de pante abrupte spre nord, vest și sud, justifică pe deplin alegerea aşezării primilor locuitori. Întrucât cercetările arheologice mai vechi au oferit date neclare cu privire la fortificarea artificială a sitului, în 2013 am deschis o secțiune pentru a verifica existența unui presupus șanț de apărare la piciorul pantei de est. A fost descoperit cu acest prilej un segment al unui şanț transversal care barează accesul dinspre terasa învecinată. În punctul în care a fost secționat, șanţul are o deschidere de aproximativ 11 metri şi o adâncime de peste 3,5 metri, coborând până în substratul geologic, reprezentat de depozite de marne.

Stratigrafia, alături de artefactele descoperite în umplutură la diferite adâncimi, indică mai multe secvențe de umplere (cea mai consistentă fiind- în timpul fazei Cucuteni A).

Secționarea în mai multe puncte a acestei structuri de pământ este necesară pentru validarea datelor prezentate.

\section{Abstract: Evidence of a Chalcolithic ditch at Bodeşti - Cetăţuia Frumuşica (Neamţ COUNTY}

Archaeological investigations carried out between 2011 and 2013 verified and confirmed some of the previously known data regarding the prehistoric habitation from Bodești - Cetătuia Frumuşica (in Eastern Romania, near Piatra Neamţ). The site preserves the remains of a Chalcolithic settlement with Cucuteni A, A-B and B layers as well as Early and Middle Bronze Age features.

The dominant position of the plateau surrounded by steep slopes towards the north, west and south fully justifies the settlement choice of the first inhabitants. As the older archaeological researches returned unclear data regarding the man-made defences of the site, in 2013 we opened a trench to verify the layout of a hypothesized earthwork of the eastern side. A segment of a transverse ditch barring the point of the easiest access was uncovered here. The ditch is about 11 metres wide and more than 3.5 metres deep, cutting through the archaeological deposits, the clay subsoil and the underlying marl bedrock

The stratigraphic evidence as well as the artefacts retrieved from various depths indicate several filling sequences (with the most consistent occurring during Cucuteni A).

Further cross-sections through this ditch are necessary in order to validate our data.

CUVINTE CHEIE: Eneolitic, Cucuteni A, fortificație, șanț.

KEYWORDS: Chalcolithic, Cucuteni, fortification, ditch. 
Publicarea în 1946 a săpăturilor lui Constantin Matasă de la Frumuşica au oferit celor interesaţi de epoca neoeneolitică un reper însemnat privind materialitatea culturii Cucuteni, atât ca bază de comparație la care s-au raportat unele descoperiri mai noi ${ }^{1}$, cât şi ca argument pentru periodizarea cucutenianului ${ }^{2}$.

Cetățuia Frumuşica ${ }^{3}$ se află la 22 de km nord-est faţă de Piatra Neamț, pe teritoriul comunei Bodești (satul Bodeștii de Jos). Este situată pe malul stâng al Cracăului (afluent al Bistriței), pe marginea terasei care se ridică astăzi cu peste 30 de metri deasupra râului.

Așa cum se delimitează în peisajul actual, situl ocupă un mic platou alungit, mai înalt cu 5-6 metri decât restul terasei, desfășurat pe direcția nord-vest - sud-est (Pl. I). La sud-est, o şa de cca. 40 de metri, flancată de două ravene adânci ${ }^{4}$, face legătura între platou și restul terasei. Depunerea antropică justifică cel mult un sfert din diferența de nivel vizibilă astăzi $(\mathrm{Pl}$. II/1, 2). Pe terasa înconjurătoare se găsesc sporadice fragmente ceramice congruente cronologiei sitului, astfel că nu poate fi exclus ca, cel puțin într-o perioadă, locuirea să fi ocupat mai mult decât cele 0,5 ha ale platoului dominant.

Sondajele arheologice şi săpăturile extinse desfăşurate în acest sit în perioada interbelică și în anii celui de-al Doilea Război Mondial ${ }^{5}$ scoteau la iveală o succesiune de locuiri eneolitice documentate în principal printr-un bogat inventar ceramic, remarcabil prin diversitate, calitate artistică şi stare de conservare. Acoperind cea mai mare parte a zonei centrale a platourilor pe care se află situl și sondând punctual zonele periferice ale acestuia, cercetările de atunci înregistrau și prezența unor amenajări cu scop defensiv puse în legătură cu etapa mai veche a locuirii.

La ceva decenii distanţă, am avut ocazia să verificăm informațiile publicate, prin investigații cu caracter intruziv derulate în cursul anilor 2011-2013.

Cercetările noastre ${ }^{6}$ au avut o amploare redusă (puțin peste $100 \mathrm{~m}^{2}$ ), fiind limitate atât de amplasamentul vechilor săpături, cât și de vegetaţia arboricolă care acoperă situl. Ținând cont de aceste circumstanțe, cele câteva secțiuni deschise în partea de est a platoului (S. I, II, IV-VI) au permis înregistrarea unei succesiuni stratigrafice complexe și cercetarea parțială a câtorva construcții (incendiate sau nu) precum și a unor amenajări de amploare, care au determinat aspectul actual al sitului.

Astfel, în cursul cercetărilor recente au fost identificate zece complexe arheologice care documentează prezențe antropice din epoca fierului (Gr. 1), epoca bronzului - perioadele mijlocie și timpurie (Cx. 1, Cx. 3) $)^{7}$ şi din eneolitic, pe parcursul fazelor B (Cx. 2 și Gr. 5), A-B (Cx. 4 și 6) $)^{8}$ și A (Cx. 5, Cx. 7 și Cx. 10) ale culturii Cucuteni. Numeroase bioperturbări afectează structurile arheologice - în special locuinţele eneolitice aflate în marginea platoului.

Ultimele investigații au permis, așadar, verificarea și nuanțarea cronologiei sitului. Reconsiderând amploarea intervențiilor antropice mai târzii de pe platoul Frumuşicăi, săpăturile au confirmat, totodată, că cele mai consistente depuneri se datează pe parcursul fazei Cucuteni A, căreia îi corespund, în sectorul cercetat de noi, trei etape de construcții pe platou și un șanț de apărare care bara accesul dinspre terasă. Această ultimă structură (Cx. 10), identificată la baza pantei de est, constituie subiectul notei de faţă.

Prezența unor structuri defensive în jurul Cetățiii a fost remarcată încă de la primele săpături desfășurate în acest sit, autorul cercetărilor incluzând în această categorie trei șanţuri de apărare (P1. 1) care marcau limitele vestice, nordice și estice ale spațiului locuit în faza Cucuteni A, precum și mai multe ,pavaje” răspândite în special de-a lungul laturilor de est și de nord ale platformei inferioare, amenajate în timpul locuirii din faza Cucuteni B'.

Şanţurile sunt prezentate succint și ilustrate schematic în volumul redactat de către C. Matasă:

a. O excavație cu deschiderea la gură de 11 metri, cu baza de 1,5 metri, care coboară cu 2,20 metri față de nivelul actual a fost observată pe latura de nord a platformei inferioare, între aceasta și platforma superioară ${ }^{10}$.

b. În buza pantei abrupte dinspre Cracău (latura de vest), secţiunea 4 a înregistrat o situație stratigrafică interpretată

1 Vezi, de exemplu, Boghian 2004; Bodi 2010; Lazarovici, Lazarovici 2012.

2 Niţu 1980; Nițu 1984; Lazarovici 2010.

3 Sau, simplu, Frumuşica, aşa cum apare de cele mai multe ori în publicații.

4 Descriind situl, Constantin Matasă nota că aceste ravene ar fi avut iniţial caracter antropic, fiind urma unui şanț săpat de către prima comunitate eneolitică stabilită aici, adâncit de factori naturali (Matasă 1946, 9).Cu o deschidere de peste 50 de metri și o adâncime care depășeşte 20 de metri, cele două viroage sunt, mai curând, formațiuni naturale.

5 Matasă 1946.

Munteanu et al. 2012; Munteanu et al. 2013; Munteanu et al. 2014.

Munteanu 2018.

Munteanu, Garvăn 2015.

Matasă 1946, 28-34.

${ }^{10}$ Matasă 1946, 29-30, fig. 10 și pl. II. 


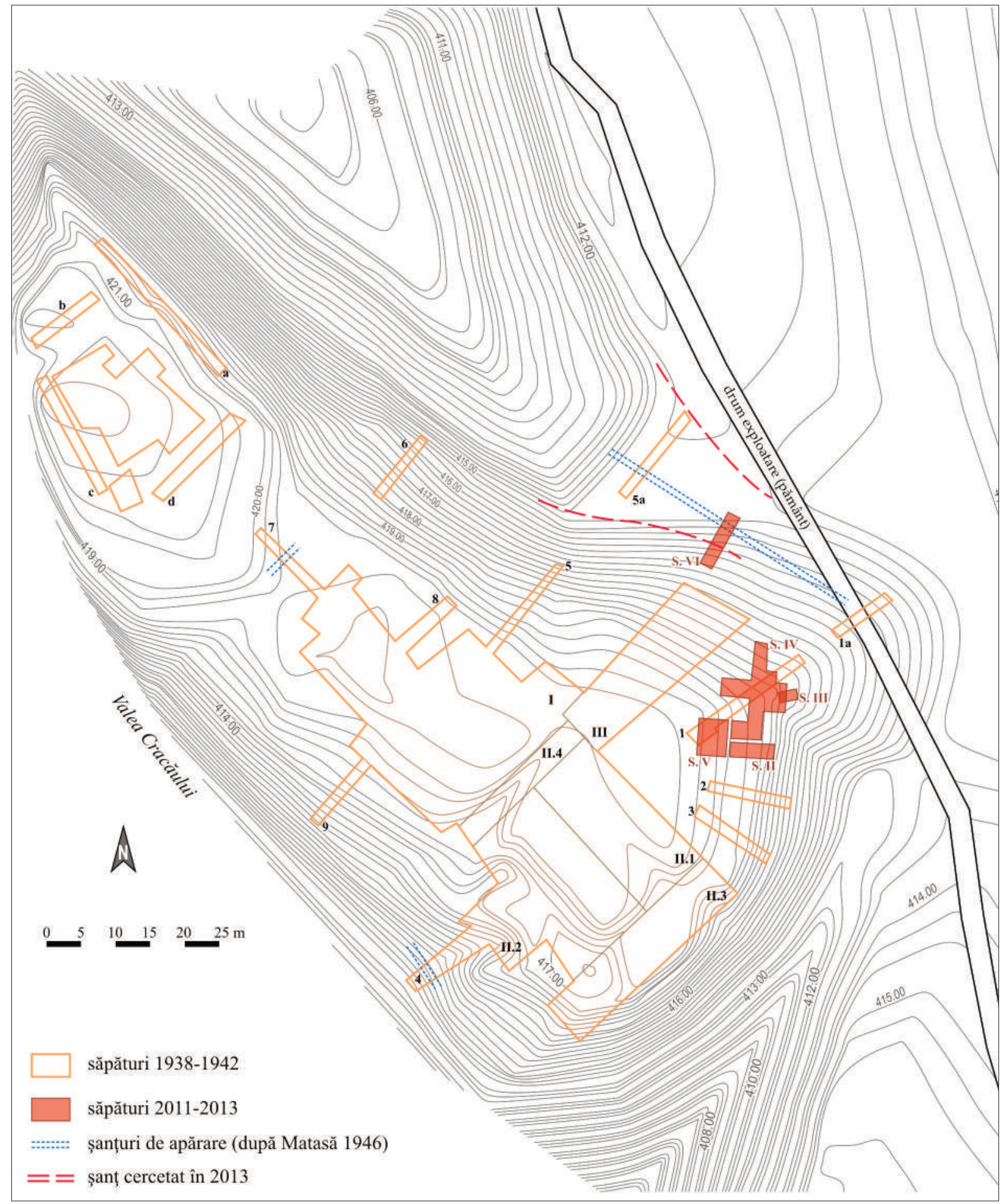

Planșa I. Bodeşti - Cetăţuia Frumuşica. Planul săpăturilor. 

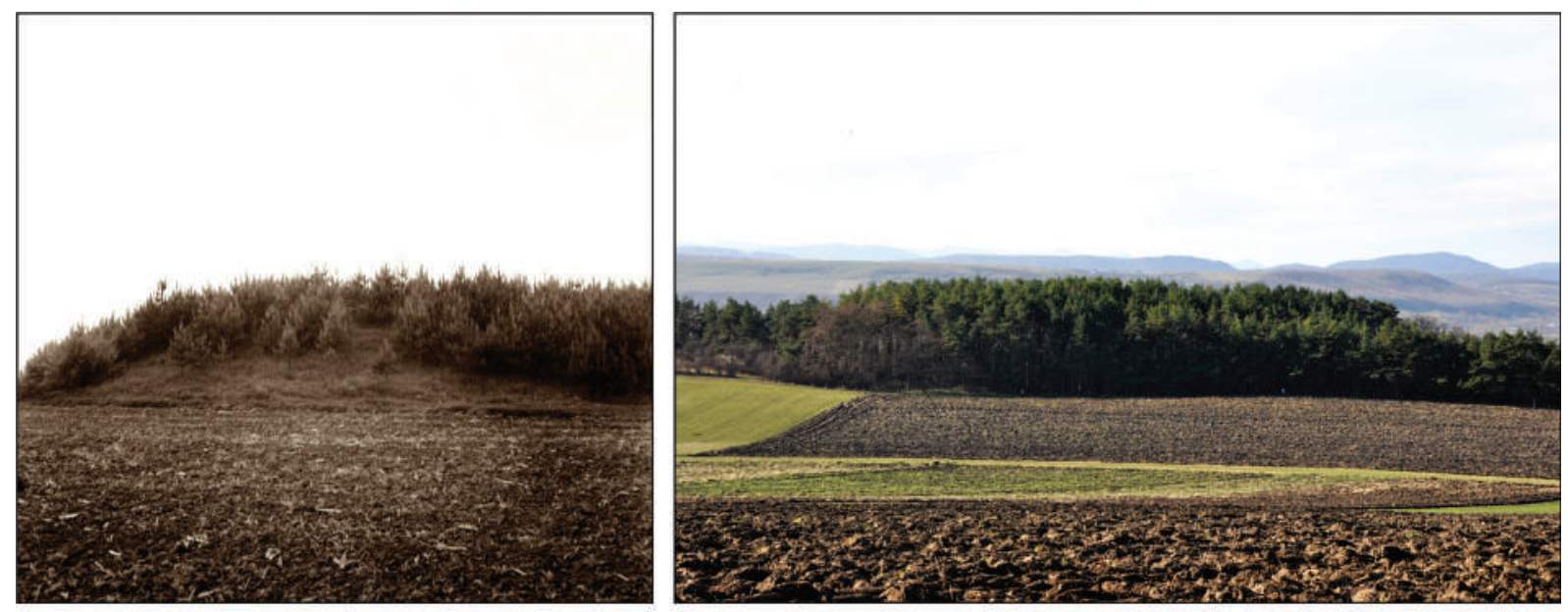

1
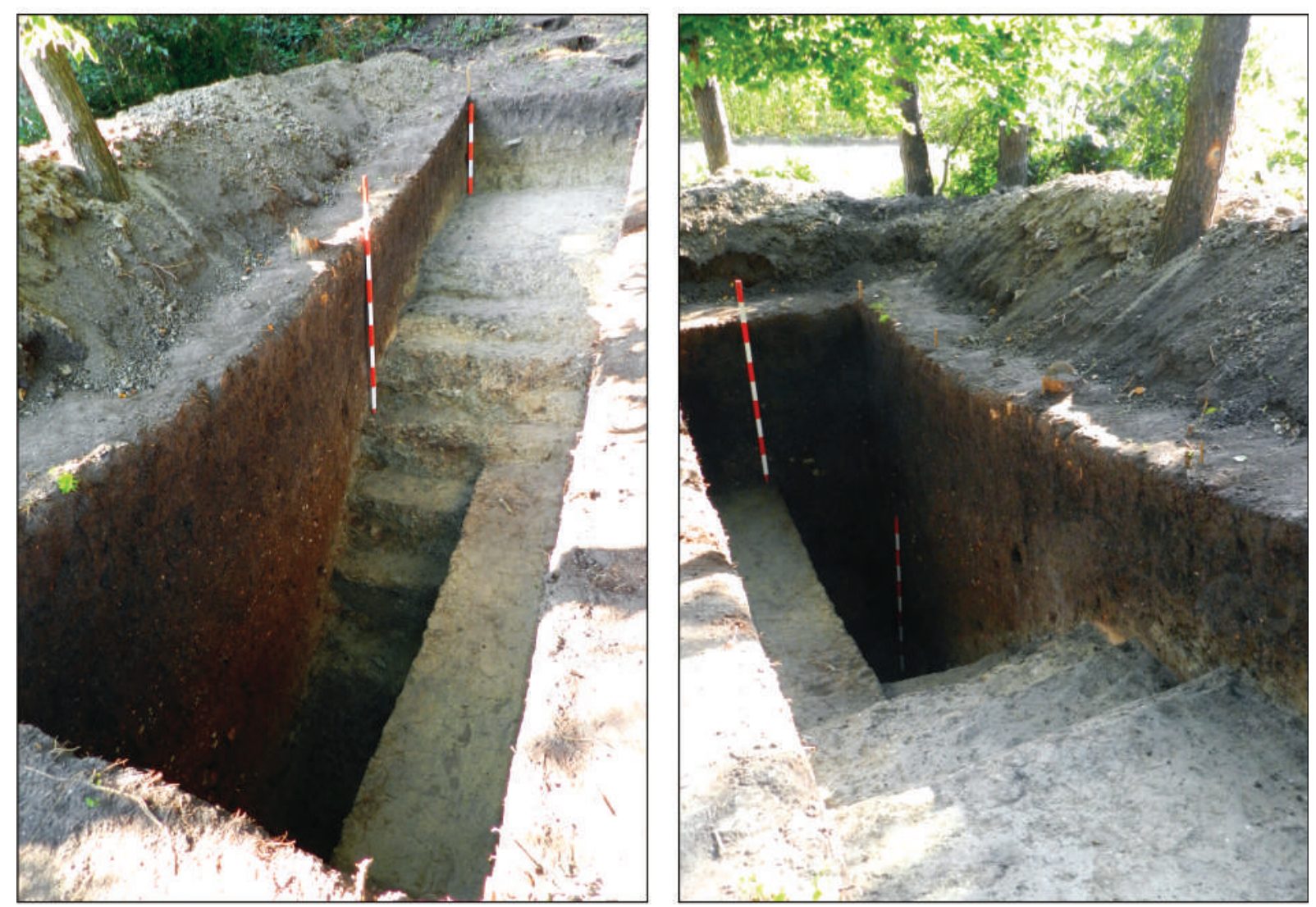

Planşa II. 1-2. Vedere asupra laturii de est a Cetăţuii în anii '70 şi 2010; 3-4. Şanţul de apărare intersectat în S. VI. 
drept rest al unui alt şanț aflat în uz în cursul fazei Cucuteni $\mathrm{A}^{11}$, distrus de alunecări de teren, după încetarea locuirii preistorice. Așa cum apare în profilul publicat, șanțul ar fi avut o lățime la bază de peste 1,5 metri și ar fi creat, la vremea săpării sale, o diferență de nivel de cel puțin 2 metri. Adâncimea față de nivelul de călcare, la data cercetării, era de 3,30 metri, în partea superioară a umpluturii (până la -2,20 metri) fiind remarcate aglomerări de pietre și fragmente ceramice Cucuteni B și A-B.

c. În ceea ce privește structurile defensive de pe latura de est a sitului, remarcăm că lucrarea monografică la care ne referim aici este lipsită de claritate, incluzând, la câteva paragrafe distanță, informații contradictorii. Deși autorul cercetărilor afirmă că secțiunea 5a nu a intersectat un șanț de apărare și că în această zonă a Cetățuii trebuie să fi existat doar o întăritură de pământ consolidată cu piatră şi lemn, rândurile următoare menționează cercetarea unui şanț pe latura de est, lângă care se găsea un zid de piatră ${ }^{12}$. Ambele structuri sunt figurate pe planul general al săpăturilor în dreptul secțiunii 5a, deși pe profilul aceleiași secțiuni nu este reprezentat un șanț ${ }^{13}$.

Astfel prezentate, datele referitoare la fortificațiile eneolitice ale Frumuşicăi nu sunt pe deplin convingătoare. La puțin timp după publicare, unele dintre structuri (şanţurile de vest și de nord) au fost considerate a fi insuficient documentate, punându-se sub semnul întrebării cronologia, poziția și anvergura lor $^{14}$.

Înainte de reluarea cercetărilor, unul dintre autorii prezentei note remarca menționarea repetată a ceramicii din epoca bronzului în legătură cu ,pavajele" de pietre dezvelite în săpăturile vechi ${ }^{15}$, asociere confirmată în cursul campaniilor din 2011-2013 ${ }^{16}$. Poate că aceleiași secvențe ocupaționale îi aparține și structura de pe latura de vest ${ }^{17}$, impropriu considerată şanț, aflată la partea superioară a unei pante abrupte, cu deschidere spre râu. Ținând cont de situarea acestei structuri, nu am urmărit verificarea sa prin săpătură, pentru clarificarea stratigrafiei și cronologiei sale.

Pentru lămurirea unora dintre incertitudinile semnalate mai sus am considerat necesară sondarea laturii de est a sitului, deschizând aici în 2013 o secțiune (Pl. I). Amplasarea S. VI a ținut cont de configurația terenului și de informațiile despre săpăturile vechi, aceasta încadrându-se la jumătatea distanței dintre suprafețele în curs de cercetare de pe platou (S. IV) și secțiunea 5a a lui C. Matasă (în dreptul căreia planul publicat indica prezența unui șanț de apărare și a unui zid). Vegetația înconjurătoare nu a permis deschiderea unei suprafețe mai mari de 8 × 2 metri.

În limitele S. VI am intersectat parțial un șanț de mari dimensiuni (Pl. II-IV), a cărui deschidere depășește în acest punct 12 metri $^{18}$ și care coboară până la $-4,00$ metri față de nivelul actual ${ }^{19}$. Partea inferioară are lățimea de $1,10-$ 1,20 metri, cea mai mare parte a excavației (între $-0,70$ și $-4,00$ metri) fiind săpată în roca dealului (marnă).

În funcție de culoare, consistență și conținut, se conturează trei etape de umplere a şanțului (Pl. III). Depunerea de la partea inferioară (între $-2,10$ și $-4,00$ metri) este omogenă, compactă, cu o consistență dură, constând dintr-un sediment argilos, brun - cafeniu, cu puține materiale arheologice (pigmenți și bulgări de chirpici, câteva fragmente ceramice). Este suprapusă de un strat (între $-1,25$ și - 2,10 metri) care se diferențiază numai prin cantitatea mai mare de material arheologic. Partea superioară a umpluturii este formată din sol compact, de culoare brun - cenuşie, în care se găsesc, de asemenea, câteva fragmente ceramice și resturi osteologice, rare pietre de mici dimensiuni și încă şi mai rari pigmenți de lipitură arsă.

Pe lângă numărul redus de artefacte antrenate în șanț, se remarcă aspectul omogen al straturilor, semnalând o umplere rapidă. Complexul este acoperit de un nivelul vegetal uniform ( 0 - 0,45 metri).

Ceramica nivelului inferior, corodată și puternic fragmentată, pare să aparțină numai fazei Cucuteni A (Pl. IV/912), în timp ce în nivelul intermediar s-au observat și câteva fragmente Cucuteni B (Pl. IV/6-8).

Nivelul superior al umpluturii (între - 0,45 și $-1,25$ metri) este neunitar din punct de vedere al materialului arheologic; au fost recuperate de aici atât fragmente ceramice cucuteniene (A și B) cât și unele specifice bronzului mijlociu - cultura Costișa (Pl. IV/3-5). Acestea din urmă corespund unui nivel ocupațional situat pe platou,

\footnotetext{
${ }_{11}$ Matasă 1946, 30-31 și fig. 11.

12 Matasă 1946, 32.

${ }^{13}$ Matasă 1946, fig. 13, pl. II.

${ }_{14}$ Petrescu 1954, p. 221, nota 41; Florescu 1966, 28.

${ }^{15}$ Munteanu 2010, 88.

${ }_{16}^{16}$ Munteanu 2018.

${ }^{17}$ Complexul semnalat în secțiunea 4 poate să fie mai curând rezultatul unor activități de terasare / transformare a aspectului înălțimii, similară celei documentate în situl eponim al culturii Costișa (Popescu, Băjenaru 2008, 31).

${ }^{18}$ Aprecierea dimensiunilor șanțului incluse în raportul de săpătură (Munteanu et al. 2014, 27-28) este una preliminară, care nu a luat în calcul reconstituirea grafică a structurii.

${ }^{19}$ Deoarece contraescarpa nu a fost dezvelită complet, adâncimea excavației în epoca în care a fost săpată este dificil de stabilit. Notăm doar că diferența între baza șanțului şi nivelul platoului depășește 10 metri și estimăm că față de terasa înconjurătoare șanțul cobora cu peste 3,5 metri.
} 


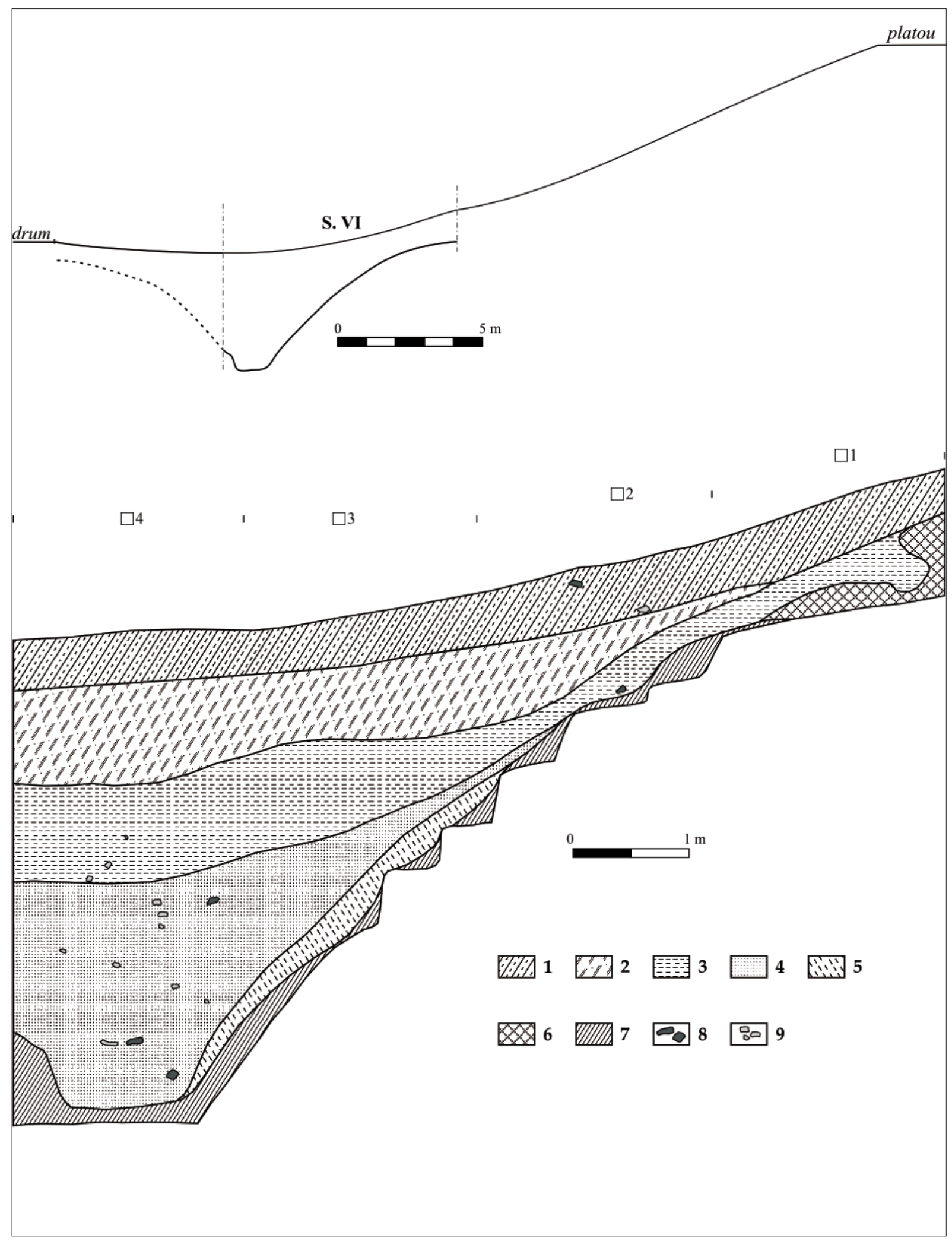

Planșa III. Profilul de sud-est al S. VI: 1. nivel vegetal, brun - cenuşiu, afânat,; 2. sol compact, de culoare brun - cenușie; 3. sol argilos, brun-cafeniu, consistenţă dură, pigmentat cu lut ars; 4. sol argilos, brun - cafeniu; 5. lentilă de lut galben, neomogen; 6. argilă galbenă (steril arheologic); 7. strat de marnă; 8. bulgări de chirpici; 9. pietre. 


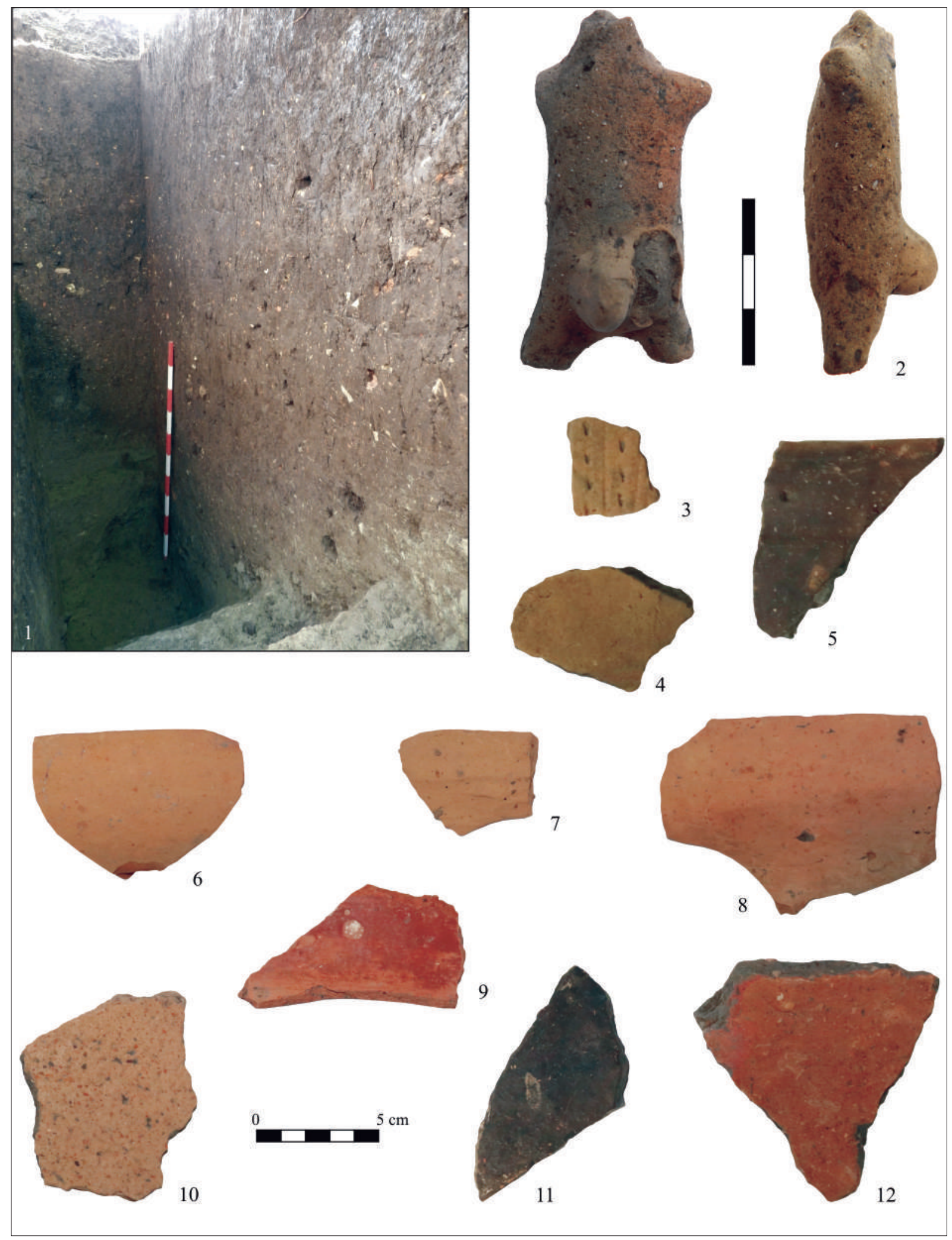

Planșa IV. 1. Detaliu al profilului de sud-est; 2. figurină antropomorfă getică; 3-12. ceramică descoperită în umplutura şanţului: (3-5. epoca bronzului; 6-8. Cucuteni B; 9-12. Cucuteni A). 
documentat atât în săpăturile vechi (acele ,pavaje” descrise în monografia din 1946), cât și în secțiunile deschise în 2011-2013 (mai ales în limitele S. V).

Din același strat acumulat în perioada dezafectării șanțului provin și unele materiale arheologice care nu își găsesc corespondent în stratigrafia platoului. Printre acestea, o figurină antropomorfă (Pl. IV/2) care poate fi atribuită sec. V-IV î.Chr. și un fragment ceramic Precucuteni III. Figurina getică se adăugă unui lot de cca. 20 de fragmente ceramice (de la vase diferite) din aceeași perioadă, descoperite la partea superioară a depunerii antropice ${ }^{20}$. În ceea ce privește perioada precucuteniană, descoperirile se rezumă, în afara fragmentului menționat, la alte câteva materiale izolate, pentru care nu se precizează poziția stratigrafică ${ }^{21}$. Deși izolate, materialele ceramice menționate indică posibilitatea unei secvențe ocupaționale mai îndelungate pe Cetățuie.

Identificarea lucrărilor de fortificare sau de delimitare ale unor aşezări cucuteniene a constituit o constantă a cercetării arheologice încă de la începutul sec. al XX-lea, odată cu săpăturile de la Cucuteni - Cetățuie, realizate de H. Schmidt ${ }^{22}$. Descoperiri asemănătoare din alte situri cucuteniene (faza A), cum ar fi cele de la Hăbășești ${ }^{23}$ sau Trușești ${ }^{24}$, dar și din alte arii culturale, au permis realizarea unor prime articole de sinteză la nivelul anilor ' $60^{25}$. Trei decenii mai târziu, numărul siturilor Cucuteni A cunoscute între Carpaţi și Prut prevăzute cu sisteme de apărare / delimitare ajungea la 17, puține dintre acestea fiind abordate prin săpături ${ }^{26}$.

Utilizarea metodelor de cercetare non-intruzive (fotogrametrie, măsurători geofizice), uneori combinate cu cele intruzive, au pus în evidență existența unor șanțuri de apărare la Poduri - Dealul Ghindaru², Fulgeriș - La 3 Cireși $i^{28}$, Costești - Cier ${ }^{29}$, Răucești - Dealul Munteni ${ }^{30}$, Războieni - Dealul Mare ${ }^{31}$ etc.

O scurtă analiză a sistemelor de fortificare atribuite fazei Cucuteni A cercetate până în prezent la est de Carpați, arată că cele mai apropiate ca dimensiuni (deschiderea la gură și adâncimea) de cel prezentat în această notă au fost identificate la Hăbășești și Fulgeriș. La Hăbășești cele două șanţuri cercetate aveau în zona centrală, în tranșeele $i$ și $j$, dimensiunile de 5-6 metri deschidere şi 2,30-2,75 metri adâncime (şanţul interior), respectiv 7,10-9 metri deschidere și 3,30-3,45 metri adâncime (șanțul exterior, acesta fiind amenajat pe o ravenă naturală) ${ }^{32}$. Pentru șanțul interior (Ș 1) de la Fulgeriș se menționează dimensiunile de 9,70 metri deschidere și 2,50 metri adâncime, iar pentru cel exterior (Ș 2) 8,20 metri deschidere și 2,12 metri adâncime ${ }^{33}$.

Remarcăm variaţia mare a dimensiunilor șanțurilor cucuteniene cercetate. La un capăt al spectrului se situează structurile menționate de la Hăbășești, Fulgeriș și Bodești, la celălalt - șanțuri precum cele de la Târpești (2-5 metri deschidere și 1,20-1,75 metri adâncime $)^{34}$, Cucuteni (2,80 metri lățime și 2 metri adâncime $)^{35}$, Costești $(2,70-2,80$ metri deschidere și 2,07 metri adâncime) $)^{36}$.

Multiple variabile influențează fiecare caz, justificând diferențele constatate, fie că ne referim la funcționalitatea diferită a șanţurilor (de apărare sau de delimitare), ori la dimensiunea comunităţilor care le creează. De asemenea, în modelarea spațiului locuit, printre factorii hotărâtori care determină amploarea structurilor, se numără rolul / prestigiul incintei astfel delimitate și, nu în ultimul rând, configuraţia terenuluii ${ }^{37}$.

Așa cum poate fi cazul și la Frumuşica, pentru unele dintre aceste amenajări dimensiunile pot suferi modificări la o verificare ulterioară, în funcție de segmentul cercetat al fiecărei structuri.

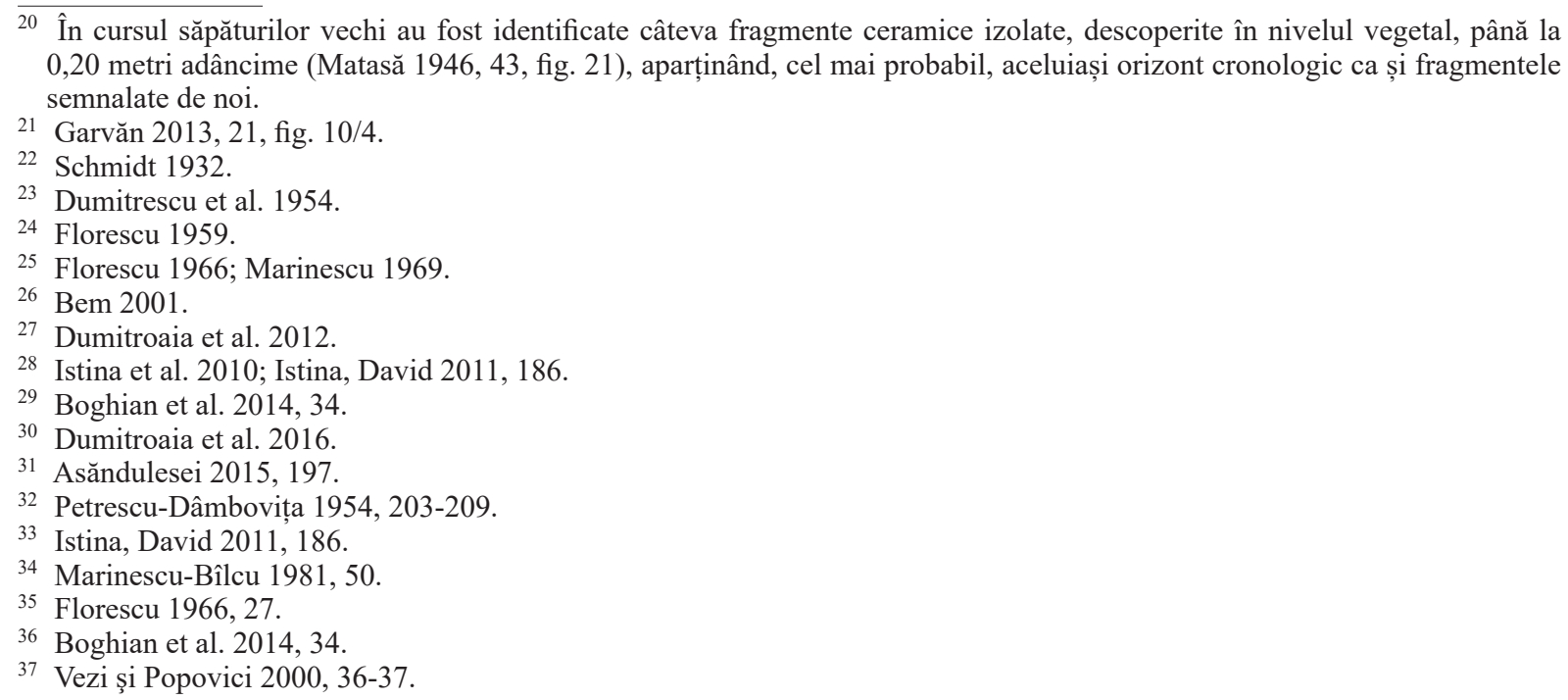


Cercetările din 2013 de la Bodești certifică, așadar, prezența unui șanț de apărare între platou și terasă. Cel mai probabil, acesta a tăiat șaua, unind cele două ravene. Informațiile stratigrafice par să confirme datele vechilor săpături, potrivit cărora lucrările de fortificare ale Cetățiii au fost realizate pe parcursul locuirii Cucuteni A, fiind scoase din uz în timpul aceleiași faze sau într-un moment imediat ulterior.

\section{BIBLIOGRAFIE}

Asăndulesei 2015

Bem 2001

Bodi 2010

Boghian 2004

Boghian et al. 2014

Dumitrescu et al. 1954

Dumitroaia et al. 2012

Dumitroaia et al. 2016

Florescu 1959

Florescu 1966

Garvăn 2013

Istina et al. 2010

Istina, David 2011

Lazarovici 2010

Lazarovici, Lazarovici 2012

Marinescu 1969

Marinescu-Bîlcu 1981

Matasă 1946
Asăndulesei, A., GIS (Geographic Information System), fotogrametrie și geofizică în arheologie. Investigații non-invazive în aşezări Cucuteni din România, Editura Universității „Alexandru Ioan Cuza”, Iași, 2015.

Bem, C., Les fortifications de l'aire Precucuteni et Cucuteni. Entre les axiomes et archétypes, CCDJ, XVI-XVII, 2001, 53-98.

Bodi, G., Hoisești - La Pod: o așezare cucuteniană pe valea Bahluiului, Editura Pim, Iași, 2010.

Boghian, D., Cultura Cucuteni în Bazinul Bahluiului, Bucovina Istorică, Suceava, 2004.

Boghian, D., Enea, S.-C., Ignătescu, S., Bejenaru, L., Stanc, S.M., Comunitățile cucuteniene din zona Târgului Frumos: cercetări interdisciplinare în siturile de la Costești și Giurgești, Editura Universității „Alexandru Ioan Cuza”, Iași, 2014.

Dumitrescu, Vl., Dumitrescu, H., Petrescu-Dâmbovița, M., Gostar, N., Hăbășești. Monografie arheologică, Editura Academiei R.P.R., București, 1954.

Dumitroaia, Gh., Ștefan, D., Munteanu, R., Garvăn, D., Nicola, D., Investigații non-intruzive la Poduri - Dealul Ghindaru, MemAntiq, XXVIII, 2012, 167-184.

Dumitroaia, Gh., Diaconu, V., Preoteasa, C., Mischka, C., Tasimova, I., Niessner, A., Hattermann M., Răucești, com. Răucești. jud. Neamț. Punct: Dealul Munteni, Cronica Cercetărilor Arheologice, Campania 2015, 2016, 69-70.

Florescu, A.C., Șantierul arheologic Trușești, MCA, V, 1959, 183-187.

Florescu A.C., Observații asupra sistemului de fortificare al așezărilor cucuteniene din Moldova, ArhMold, IV, 1966, 23-37.

Garvăn, D., Contribuții la cunoașterea culturii Precucuteni, Biblioteca Memoriae Antiquitatis XXX, Editura Constantin Matasă, Piatra Neamţ, 2013.

Istina, L.E., Asăndulesei A., Vornicu, D.-M., Venedict, B., Balaur R., Fulgeriș, com. Pâncești, jud. Bacău. Punct: Dealul Fulgeriș / La 3 Cireși, Cronica Cercetărilor Arheologice, Campania 2009, 2010, 263-265.

Istina, L.E., David, D.-C., Fulgeriş, com. Pâncești, jud. Bacău. Punct: Dealul Fulgeriș / La 3 Cireși, CCA. Campania 2010, 2011, 185-187.

Lazarovici, Gh., Despre fazele A1 ale Grupelor Ariuşd și Cucuteni, Angustia, 10, 2010, 27-108.

Lazarovici, C.M., Lazarovici, Gh., Ruginoasa - Dealul Drăghici: monografie arheologică, Editura Karl A. Romstorfer, Suceava, 2012.

Marinescu Fl., Așezări fortificate neolitice din România, StCom Sibiu, 14, 1969, 7-32.

Marinescu-Bîlcu, S., Tîrpești. From Prehistory to History in Eastern Romania, BAR, International Series, 107, Oxford, 1981.

Matasă, C., Frumușica. Village préhistorique à céramique peinte dans la Moldavie du Nord Roumanie, Imprimeria Națională, București, 1946. 
Munteanu 2018

Munteanu et al. 2012

Munteanu et al. 2013

Munteanu et al. 2014

Munteanu, Garvăn 2015

Niţu 1980

Niț 1984

Petrescu-Dîmbovița 1954

Popescu, Băjenaru 2008

Popovici 2000

Schmidt 1932
Munteanu, R., Începutul bronzului timpuriu în Estul României: observații privind valoarea cronologică a orizonturilor ceramice, în baza descoperirilor de la Bodești - Cetăţuia Frumuşica, Mousaios, XXII, 2018, 141-172.

Munteanu, R., Dumitroaia, Gh., Garvăn, D., Nicola, D., Uță, L., Bodeștii de Jos, com. Bodești, jud. Neamț. Punct: Cetățuia Frumușica, Cronica Cercetărilor Arheologice, Campania 2011, 2012, 20.

Munteanu, R., Dumitroaia, Gh., Garvăn, D., Nicola, D., Bodeștii de Jos, com. Bodești, jud. Neamț. Punct: Cetățuia Frumușica, Cronica Cercetărilor Arheologice, Campania 2012, 2013, 20-21.

Munteanu, R., Dumitroaia, Gh., Garvăn, D., Nicola, D., Buzea, D., Bodeștii de Jos, com. Bodești, jud. Neamț. Punct: Cetățuia Frumuşica, Cronica Cercetărilor Arheologice, Campania 2013, 2014, 27-28.

Munteanu, R., Garvăn, D., Câteva date despre o structură neincendiată Cucuteni A - B descoperită la Bodeștii de Jos „Cetățuia Frumușica”, BMJT, 7, 2018, 117-132.

Nițu, A., Criterii actuale pentru clasificarea complexelor ceramicii și periodizarea etapelor culturii cucuteniene, CI, XI, 1980, 135-222.

Nițu, A., Formarea și clasificarea grupelor de stil AB și B ale ceramicii pictate Cucuteni-Tripolie, AIIA - Supliment V, Editura Academiei R.S.R., Iaşi, 1984.

Petrescu-Dîmbovița, M., Șanțurile de apărare, în Hăbășești. Monografie arheologică, Editura Academiei R.P.R., București, 1954.

Popescu, A.-D., Băjenaru, R., Mortuary practices at Costișa (Neamț County), Dacia, N.S., LII, 2008, 23-47.

Popovici, D.N., Cultura Cucuteni. Faza A. Repertoriul aşezărilor, Biblioteca Memoriae Antiquitatis, VIII, Editura Constantin Matasă, Piatra Neamț, 2000.

Schmidt, H., Cucuteni in der oberen Moldau, Rumänien, Waler de Gruyter \& Co: Berlin-Leipzig, 1932.

\section{LIST OF ILLUSTRATIONS}

Plate I. Bodeşti - Cetăţuia Frumuşica. Layout of the archaeological excavations.

Plate II. 1-2. View of the eastern slope of Cetăţuia in the seventies and in 2010;3-4. Part of the enclosure ditch under research in Trench VI.

Plate III. South-eastern profile of Trench VI: 1. recent layer (loose, greyish-black soil); compact layer of greyish black soil; 3. compact layer of brown - yellowish soil, with burnt clay pigments; 4. brown - yellow, compact layer, low rate of pottery; 5 . yellowish clay; 6 . geological strata - yellow clay; 7. geological strata - marlstone; 8 . burnt wattle and daub lumps; 9. stones.

Plate IV. 1. Stratigraphic detail; 2. Iron Age human-shaped clay figurine; 3-12. pottery shards from the ditch (3-5. Middle Bronze Age; 6-8. Cucuteni B. 9-12. Cucuteni A).

ROXANA MUNTEANU,

Muzeul Județean Buzău, roxmunteanu@gmail.com

DANIEL GARVĂN, Muzeul Judeţean Buzău, daniel.garvan@gmail.com 